\title{
Boosting Students' Excitement during Long Online Course using Combination of Online Course Platforms and Social Media Based Assignments
}

\author{
Muhfizaturrahmah $^{1 *}$, Yulieda Hermaniar ${ }^{2}$, Yasyir F. Mubaraq ${ }^{3}$ \\ ${ }^{1}$ Department of Electrical Engineering Education, Yogyakarta State University \\ ${ }^{2,3}$ English Department, STKIP PGRI Banjarmasin \\ ${ }^{1}$ muhfizaturrahmah@uny.ac.id*, ${ }^{2}$ yuliedahermaniar@stkipbjm.ac.id, ${ }^{3}$ myasyirfahmi@ @tkipbjm.ac.id \\ * corresponding author
}

\begin{tabular}{|c|c|}
\hline ABSTRACT & Article Info \\
\hline $\begin{array}{l}\text { Months of online courses create students' boredom leading to their decreasing } \\
\text { involvement on teaching and learning process. This paper reports how social } \\
\text { media based assignment such as Instagram, Whatsapp, and Youtube fills the void } \\
\text { and bring back students' courage to a better level during covid19 lockdown. This } \\
\text { is a qualitative study using narrative approach which data was collected } \\
\text { collaboratively during even semester of } 2019 \text { at English Courses of Department } \\
\text { of Electrical Engineering Education Yogyakarta State University and Study } \\
\text { Program of English Literature STKIP PGRI Banjarmasin. The data carried from } \\
\text { multiple e-learning applications indicates that the more we adopt social media } \\
\text { based assignment, the more students were engaged into the class activities and } \\
\text { the higher level of involvement was observed. }\end{array}$ & $\begin{array}{r}\text { Article history } \\
\text { Received: March } 3^{\text {rd }}, 2021 \\
\text { Revised: May } 20^{\text {th }}, 2021 \\
\text { Accepted: May, } 30^{\text {th }}, 2021 \\
\text { Keywords } \\
\text { boredom, } \\
\text { decreasing involvement, } \\
\text { social media, } \\
\text { e-learning student's }\end{array}$ \\
\hline ABSTRAK & \\
\hline $\begin{array}{l}\text { Pembelajaran online yang berlangsung selama berbulan-bulan memicu } \\
\text { kebosanan peserta didik yang menyebabkan penurunan keikutsertaan mereka } \\
\text { dalam proses belajar mengajar. Penelitian ini bertujuan untuk mengetahui } \\
\text { bagaimana tugas berbasis media sosial seperti Instagram, Whatsapp, dan Youtube } \\
\text { dapat mengisi kekosongan dan mengembalikan keberanian peserta didik menjadi } \\
\text { lebih aktif selama lockdown covid19. Penelitian ini merupakan penelitian } \\
\text { kualitatif dengan pendekatan naratif yang datanya dikumpulkan secara } \\
\text { kolaboratif selama semester genap tahun } 2019 \text { pada mata kuliah Bahasa Inggris } \\
\text { di Jurusan Pendidikan Teknik Elektro, Universitas Negeri Yogyakarta dan } \\
\text { Program Studi Bahasa Inggris STKIP PGRI Banjarmasin. Data yang dihasilkan } \\
\text { dari beberapa aplikasi e-learning menunjukkan bahwa semakin kita mengadopsi } \\
\text { tugas berbasis media sosial, semakin banyak peserta didik yang terlibat dalam } \\
\text { kegiatan kelas dan tingkat keikutsertaan menjadi lebih tinggi. }\end{array}$ & \\
\hline
\end{tabular}

\section{INTRODUCTION}

In the age of Covid-19 pandemic, online class is no longer an option for educators. The pandemic has shifted the face to face interaction into varied e-learning platform. Online classroom applications such as Google
Classroom, Edmodo, Kahoot, etc. are the ones with highest downloader over the past months. As many teachers use the applications, there are many others who use existing social media instead. The use of social media is believed as the reflection of real life interaction which 
allows students to communicate and study at the same time.

The use of social media such as WhatsApp, Instagram, and YouTube during the stay-athome time is never been higher. The people are forced to stay inside, the only social interaction happens on the applications. People post, comment, share videos, etc. to kill the boredom. E-learning application or LMS (Learning management system), instead, become the students" "enemy" since they deal with theories and assignments under specific deadlines. Both social media and e-learning apps are internet based activity but offer different experience. When e-learning apps give individualistic ambience in terms of task completion, Selwyn (2012) stated that social media create mass socialization which harnesses the power of the collective action of online user communities rather than individual users. However, despite the fun and the meaningfulness, the use of LMS in formal institution cannot be neglected. The systematic interface, sources and file shared features are very helpful for the teachers to teach during the pandemic. While social media play fun part of the learning, LMS offers real classroom situation where there are rules, time allotment for each teaching stage, and interactions. While social media and LMS such Edmodo, Google classroom, etc. are beneficial for teaching especially during the pandemic of COVID-19 where the face to face classroom is prohibited, both work in different ways which interesting to be discussed further.

The idea of community involvement brought by social media and LMS is underlined as the effort to create meaningful learning. In language teaching, meaningfulness is emphasized as important aspect. Karppinen (2005) highlight the characteristics of meaningful learning; 1) active, 2) constructive and individual, 3) collaborative and conversational, 4) contextual, 5) guided, and 6) emotionally involving and motivating. Those characteristics are also revealed from the assignment given through social media in the English teaching in higher education level.
Hence, the researchers try to narratively carry out the teaching and learning process of English in the age of pandemic by pointing out the process of assignment given through social media and LMS. This research describes kinds of assignment, task and instruction given by the lecturer at State University of Yogyakarta and STKIP PGRI on English course and carries out the way the assignment boost students participation in language learning.

The remainder of the paper is organized as follows. In Section 2, we will have a look back at related works that has been studied in the last two decades followed by method of the research done in Section 3. The result and discussion of the improvement is presented in Section 4 with conclusion and future works closing this paper.

\section{LITERATURE REVIEW}

Adult learners have their own characteristics and also need special condition in teaching them. Cercone (2008) illustrates that adult learners are autonomous, independent, and self-reliant, and they are self-directed toward goals. So, when facing adult learners, the lesson needs a measurable impact to make them be engaged and internalize the lesson. Teachers should offer group projects that inspire true collaboration and exploration. If your students can arrive at the topic on their own, it will resonate more. Cercone also stated that adult learners need scaffolding to be provided by instructor. Adult learners also need to connect the past learning to their new language. Adults need to self-reflect on the course to learning process and be given support discuss the process of learning for transformational learning. Adults need dialogue and social interaction must be provided.

Harmer (2007) also defined some characteristics of adult. First, they can engage with abstract thought. Second, they have a whole range of life experiences to draw on. Third, they already have their patterns of learning. Fourth, adult tends to be more 
discipline than other age groups. Fourth, they often have a clear understanding why they need to learn. On the other hand, they also can be very critical to the teaching method. They also can be very anxious because of their school past experience.

Brown (2016) summarized some advantageous of using computer component in language learning as follows: a) opportunity for learners to notice language forms; b) a means for providing optimal modified input to learners; c) multimodal (visual, auditory, written) practice; d) immediate, personalize feedback; e) individualization in a large class; f) self-pacing; g) private space to make mistakes; h) convenient mode for [distance] teacher feedback; i) convenient venue for [written] practice of the L2; j) collaborative projects; $\mathrm{k}$ ) variety resources available and learning styles; 1) the fun factor.

Related to those explanation, the term social media in higher education typically use interchangeably with Web 2.0. Social media is defined more specifically as "a group of Internet based applications that build on the ideological and technological foundations of Web 2.0, and that allow the creation and exchange of user generated content" (Kaplan \& Haenlein, 2010, p. 61). Mottiwalla (2007) conducted similar studies and stated that mobile learning "combines individualized learning with any time and anywhere learning" (p.2). Further, some reseachers have defined mobile learning as learning facilitated by mobile devices (Herrington \& Herrington, 2007; Mobile Learning Network (MoLeNET), 2007, 2009; MoLeNET, 2007; Valk, Rashid, \& Elder, 2010).

\section{METHOD}

This study is a descriptive qualitative research. Students were given social media based assignments to encourage their involvement in teaching learning process. Three social medias, Instagram, Whatsapp, and Youtube were utilized as media to submit students' assignments and several online course platforms including Edmodo were used as forum of discussion for feedback once the tasks done.

Researchers worked with hundreds of students. The data was taken collaboratively at Department of Electrical Engineering Education, English Department of Yogyakarta State University and STKIP PGRI Banjarmasin during Even semester of 2019 when Covid19 pandemic arisen and massive online learning were chosen as substitutes for traditional classes in Indonesia.

The main data was collected from the records of students' assignments, the discussion and their scores.

\section{RESULTS AND DISCUSSION}

The usage of social media as a way for young adults spending most of their free time connecting to people has been highly increasing, particularly after lockdown period in Indonesia which started around March 2020 varied depends on location. Each social media keeps on updating its range of services and tools which spoils users to the level of making them use most of their time engaging in social media. Facebook has brand new feature called 'Room' which function like Zoom meeting where people can have video conferencing.

Each social media offers its own specialty, from Facebook $(\mathrm{Fb})$ for sharing stories, Instagram (Ig) for sharing pictures, Youtube (Yt) for sharing videos, and the simple Whatsapp (WA) for sharing quick update. Mutiaraningrum (2014) also exposed that facebook can support students' self-directed learning. The highlights and features offered by four social media are presented in Table 1. 
Table 1. The Features of Most Popular Social Media in Indonesia

\begin{tabular}{lcccc}
\hline & Fb & Ig & Yt & WA \\
\hline Video & $\sqrt{ }$ & $\sqrt{ }$ & $\sqrt{ }$ & $\sqrt{ }$ \\
Picture & $\sqrt{ }$ & $\sqrt{ }$ & $\sqrt{ }$ & $\sqrt{ }$ \\
Story & $\sqrt{ }$ & $\sqrt{ }$ & $\sqrt{ }$ & $\sqrt{ }$ \\
Live & $\sqrt{ }$ & $\sqrt{ }$ & $\sqrt{ }$ & $\sqrt{ }$ \\
Caption Limit & - & - & - & $\sqrt{ }$ \\
Ads & $\sqrt{ }$ & $\sqrt{ }$ & $\sqrt{ }$ & - \\
\hline
\end{tabular}

Although all four social medias tried to accommodate their users with up to dated features needed by modern and dynamic people nowadays, still there are some limitations such as caption limit on Whatsapp which only allows up to 700 characters and Facebook story video which only allows up to 30 second recording.

In this study, students were given assignments which they need to post online on their social media account and share the link, tag, or send the screenshot to notify the lecturer. The students were given freedom to choose social media platform they prefer to use. Regarding this matter, social media such as facebook break the time limitation for practicing English as underlined by Azis (2011). Some examples of students' works are shown in Figure 1 and Figure 2.

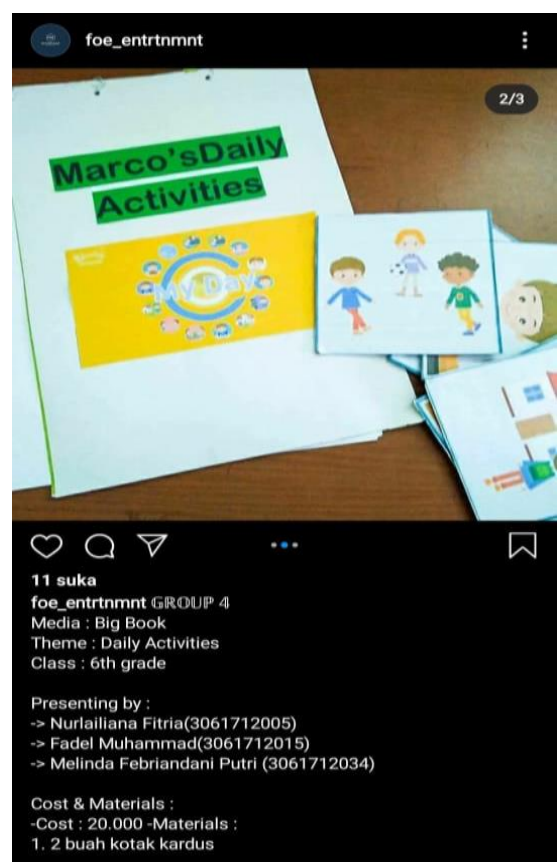

The online learning platforms namely Edmodo, Google Classroom (GC) and YSU owned online learning platform called Besmart are used to create space for discussion between the students and their teacher. The students' activeness could be observed by their instant response on comment section of the post (see Figure 3).

Edmodo was chosen for its low cost data spent and it allows student to send their recording file for example pronunciation class. Furthermore, the teacher is able to lock the time limit for assignment submission.

As the class went by, it was seen that the students show more interest if the task they were given using social media as the platform. The excitement arise could be observed in the way they proudly show their postings to their friends and lecturers, their questions following the assignments and the lively class environment created. According to an in-depth interview, they consider this type of assignment is suitable for millennial who spend their times actively on social media on daily basis. They also stated the use of social media could improve their vocabulary and their ability to construct sentence naturally.

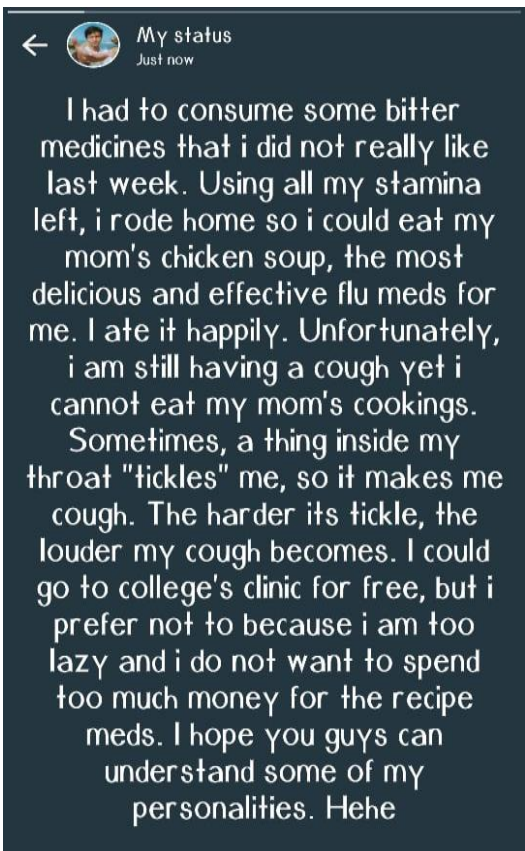

Figure 1. Creating learning media and share it online 

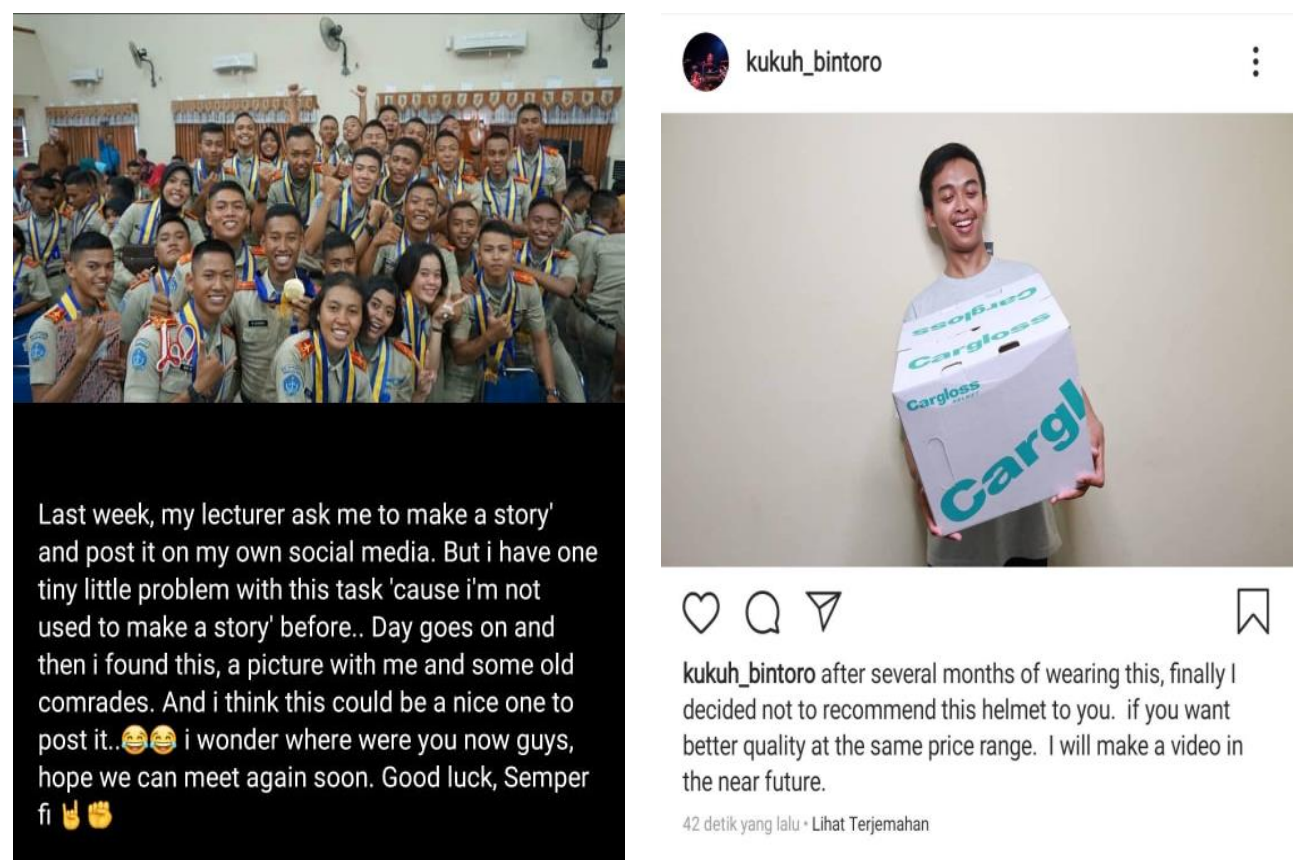

kukuh_bintoro after several months of wearing this, finally I decided not to recommend this helmet to you. if you want better quality at the same price range. I will make a video in the near future.

42 detik yang lalu : Lihat Terjemahan

Figure 2. Creating learning media and share it online
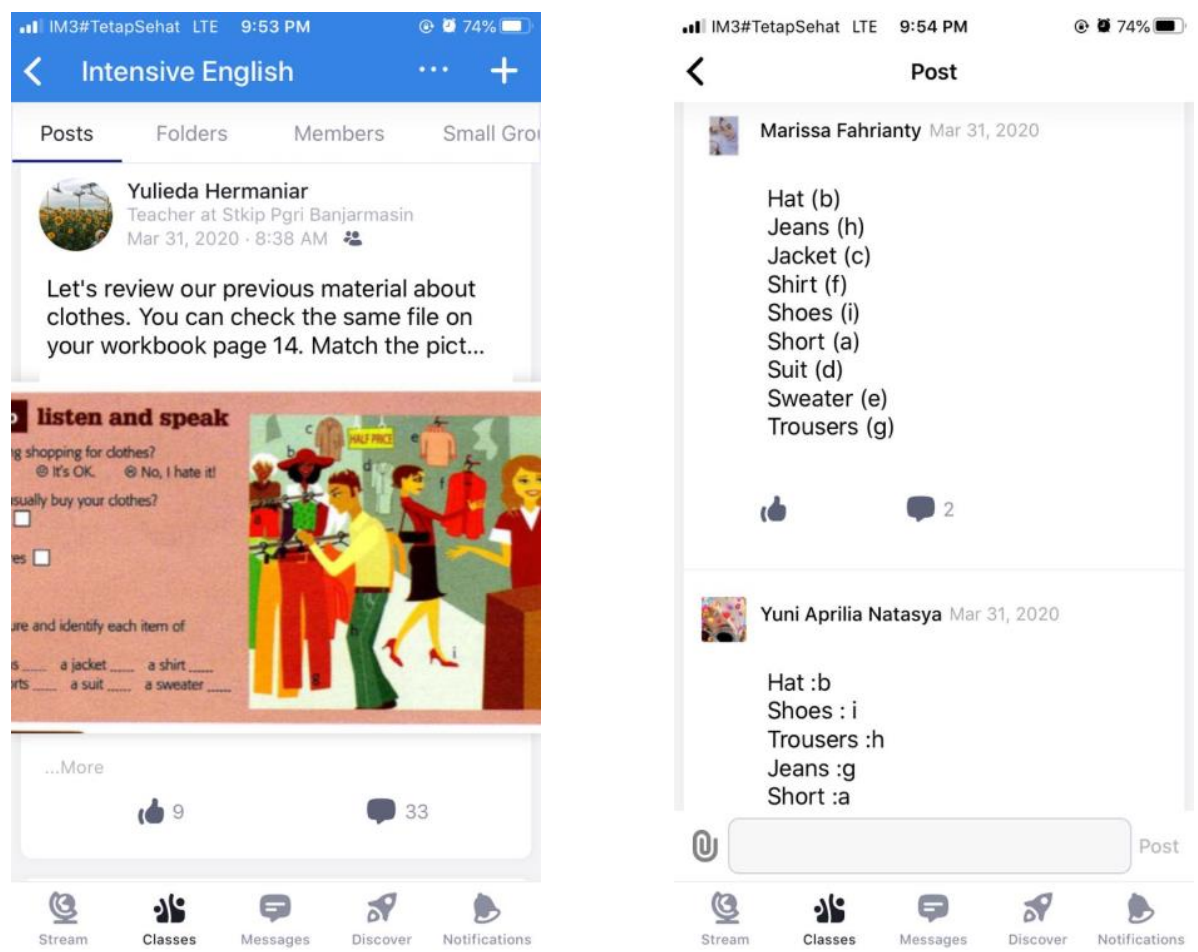

Figure 3. Class Engagement through Comment Section of Edmodo

\section{CONCLUSIONS}

The combination of social media and online course platform serves to enhance student involvement in teaching learning process. Student felt the assignment was not really an assignment thus the heavy burden of typical task was decreased. The students also found the social media based assignment to be a way to improve their vocabulary and phrase construction through a fun way. 
In the future, the researchers would like to investigate quantitatively the benefits of using social media based assignments in students' English proficiency score.

\section{REFERENCES}

Selwyn, N. 2012. Social Media in Higher Education. The Europe World Learning. 1: $1-10$

Karpinnen, P. 2005. Meaningful Learning with Digital and Online Videos: Theoretical Perspectives. Association for the Advancement of Computing in Education (AACE) Journal. 13. 3, 233-250.

Cercone, K. 2008. Characteristics of Adult Learners with Implications for Online Learning Design. Association for the Advancement of Computing in Education (AACE) Journal. 16. 2, 137-159.

Harmer, J. 2007. The practice of English Language Teaching. United Kingdom: Longman.

Brown, H. D. 2016. Teaching by Principles. New York: Longman.

Kaplan, A. M., \& Haenlein, M. 2010. Users of The World, Unite! The Challenges and Opportunities of Social Media. Business Horizons. 53: 59-68.

Mottiwalla, L. F. 2007. Mobile learning: A framework and evaluation. Computers in Education. 49. 3, 581-596.

Herrington, A., \& Herrington, J. Authentic Mobile Learning in Higher Education. Paper presented at Australian Association for Research in Education. https://www.aare.edu.au/07pap/her07131 .pdf Retrieved October 16, 2020.

Mobile Learning Network (MoLeNET). The Impact of Mobile Learning: Examining What It Means for Teaching and Learning. London: Learning \& Skills Network. http://www.molenet.org.uk Retrieved October 16, 2020.
Mobile Learning Network (MoLeNET). What is Mobile Learning. http://www.molenet.org.uk Retrieved October 16, 2020.

Valk, J., Rashid, A. T., \& Elder, L. 2010. Using Mobile Phones to Improve Educational Outcomes: An Analysis of Evidence from Asia. International Review of Research in Open and Distance Learning. 11. 1, 117-140.

Mutiaraningrum, Ira, et al. 2014. Investigation of The Use of Facebook In Supporting Students English Self-directed Learning. Jurnal Pendidikan dan Pembelajaran Untan. 3. 3, 10.

Azis, Aulia Luqman. 2011. Breaking the time limitation in the English Classroom through the use of Facebook page: A preliminary model. In Best Pratices in the Teaching on English. (Cahyono, Bambang Yudi and Cahyani, Hilda) Eds. Universittas Negeri Malang: Malang . 457-467. 